\title{
Cell-Penetrating Peptides: a Useful Tool for the Delivery of Various Cargoes Into Cells
}

\author{
E. BÖHMOVÁ ${ }^{1 *}$, D. MACHOVÁ ${ }^{1 *}$, M. PECHAR ${ }^{1}$, R. POLA $^{1}$, K. VENCLÍKOVÁ $^{1}$, \\ O. JANOUŠKOVÁ ${ }^{1}$, T. ETRYCH ${ }^{1}$ \\ ${ }^{1}$ Institute of Macromolecular Chemistry of the Czech Academy of Sciences, Prague, Czech \\ Republic \\ *These authors contributed equally to this work.
}

Received May 24, 2018

Accepted June 28, 2018

\begin{abstract}
Summary
Cell-penetrating compounds are substances that enhance the cellular uptake of various molecular cargoes that do not easily cross the cellular membrane. The majority of cell-penetrating compounds described in the literature are cell-penetrating peptides (CPPs). This review summarizes the various structural types of cell-penetrating compounds, with the main focus on CPPs. The authors present a brief overview of the history of CPPs, discuss the various types of conjugation of CPPs to biologically active cargoes intended for cell internalization, examine the cell-entry mechanisms of CPPS, and report on the applications of CPPs in research and in preclinical and clinical studies.
\end{abstract}

\section{Key words}

Cell-penetrating peptides $\bullet$ Cell penetration • Peptides • Drug delivery

\section{Corresponding author}

E. Böhmová, Department of Biomedicinal Polymers, Institute of Macromolecular Chemistry of the Czech Academy of Sciences, Heyrovského nám. 2, 16206 Prague 6, Czech Republic. E-mail: bohmova@imc.cas.cz

\section{Introduction}

Drugs that are to be transported from the bloodstream to the target cells must overcome cell membranes, which are formed by an amphiphilic phospholipid bilayer. Small hydrophobic compounds cross the cell membrane relatively easily, by diffusion. However, hydrophilic substances dissolved in the blood or bound to plasma proteins are not able to penetrate the membrane without energy-dependent processes. Similarly, macromolecular substances that can serve as carriers of hydrophobic drugs do not cross the cell membrane directly but need to be transported to the cytoplasm, usually via energy-dependent mechanisms (Hampl et al. 2015). Cell-penetrating compounds are substances that can penetrate the cells via both energydependent and energy-independent processes, and can be used to deliver various "cargoes" into cells. The cargo can consist of either a low-molecular-weight drug or a macromolecular delivery system that also includes other components such as targeting ligands (Bohmova and Pola 2016) and diagnostic labels. Cell-penetrating peptides (CPPs), on which we mainly focus in this review, represent the largest and most thoroughly studied class of cell-penetrating compounds.

CPPs are usually short oligopeptides consisting of 5-30 amino acid residues. Both their chemical structure and conformation are highly variable; their only common feature is the ability to penetrate the cell membrane without the involvement of energy-dependent processes. CPPs' major disadvantages include the lack of cell-type selectivity, the impossibility of oral administration, and low plasma half-life due to enzymatic degradation and renal filtration (Mie and Mørck 2015). 


\section{History of CPPs}

In 1988 and 1989, CPPs were described independently by two scientific research groups, both of whom reported on peptides derived from the transactivator of transcription (HIV-1 TAT) protein of the human immunodeficiency virus. The primary role of this protein is to enhance the efficiency of viral transcription and replication. Both publications described the synthesis of shorter oligopeptides derived from the HIV-1 TAT protein and the ability of these oligopeptides to penetrate cell membranes (Green and Loewenstein 1988, Viscidi et al. 1989). The resulting peptide sequence, GRKKRRQRRRC, which showed the highest penetration efficiency, was termed TAT (Vivès et al. 1997).

In 1994, penetratin (RQIKIWFQNRRMKWKK), a CPP consisting of 16 amino acids, was identified. This peptide is derived from the third $\alpha$-helix of the Antennapedia-based homeoprotein, which was first discovered in Drosophila (Derossi et al. 1994).

Lin et al. (1995) described the peptide AAVLLPVLL-AAP, which was derived from the structure of the hydrophobic region of Kaposi's fibroblast growth factor (K-FGF). It was shown that the peptide was able to efficiently penetrate the cell nucleus.

One year later, two other CPPs were reported: peptide VTVLALGALAGVGVG, containing residues 747-762 of the C-terminal segment of human integrin $\beta_{3}$, and peptide YKSAVTTVVNPKYEGK, representing the homologous portion of the integrin $\beta_{1}$ cytoplasmic tail (residues 788-803) (Liu et al. 1996).

The connection of the neuropeptide galanin and the peptide toxin mastoparan, which is present in wasp venom, led to the discovery of a new CPP. This consisted of the 27-amino-acid sequence GWTLNSAGYLLGKINLKALAALAKKIL, referred to as transportan (Pooga et al. 1998).

Many other CPPs were reported during the following years: for example, peptide pVEC (LLIILRRRIRKQAHAHSK) (Elmquist et al. 2001), which originated from the structure of vascular endothelial cadherin (CD144); or Pep-1 (KETWWETWWTEWSQPKKKRKV), consisting of three domains. The first segment, KETWWETWWTEW, enables efficient cell membrane targeting thanks to the hydrophobic interactions of tryptophan with proteins of the cell membrane. The second domain is the lysine-rich hydrophilic part, KKKRKV, which is derived from the nucleus localization sequence (NLS) of Simian virus 40
(SV-40). The remaining third part containing proline serves as a flexible linker between the two other domains.

The peptide sequence CSIPPEVKFNKPFVYLI (C105Y) and its shorter version, PFVYLI, were derived from $\alpha 1$-antitrypsin, and were reported in 2006 (Rhee and Davis 2006).

The $\mathrm{pH}$ low-insertion peptide (pHLIP), a 38-peptide derived from the bacteriorhodopsin $\mathrm{C}$ helix, has the fascinating ability to switch from a random coil conformation to an $\alpha$-helix that penetrates the cell membrane within a few seconds, when the $\mathrm{pH}$ falls below 7.0 (Reshetnyak et al. 2006). Therefore, this peptide and its applications would merit a separate review.

Since the discovery of CPPs more than 25 years ago, the number of scientific publications demonstrating the use of CPPs for delivery of various cargoes is still growing.

\section{Structural classification of CPPs}

CPPs can be classified according to various criteria such as their chemical structure, the natural protein from which they are derived, or the mechanism of cell entry. In this review, we classify CPPs based on their chemical structures. The various resulting structures also affect the ability of peptides to penetrate cell membranes.

\section{Cationic CPPS}

Positively charged peptides contain multiple lysine and arginine residues. Polyarginines are a very well-studied group of CPPs. For instance, Tünnemann et al. (2007) demonstrated that a minimum of eight arginine residues are required for enhanced cell membrane penetration; a higher number further increases the penetration efficiency.

In another work, the preparation of oligopeptides with 4, 6, 8, 10, 12, and 16 arginine residues was described (Futaki et al. 2001). It was shown that while R4 had extremely low transfection activity, R6 and R8 exhibited maximal internalization into the cells and accumulation in the nucleus. Surprisingly, a higher number of arginines led to a lower level of internalization. A complex of peptide R16 with a model protein did not show any significant internalization.

Among the CPPs containing multiple Lys or Arg residues, TAT peptide (GRKKRRQRRR) and penetratin (RQIKIWFQNRRMKWKK) are the most studied. They also act as nuclear localization sequences (NLSs), which will be described later. Both peptides penetrate all types 
of mammalian cells except two types of epithelial cells: CaCO-2 (colonic carcinoma cells) and MDCK (MadinDarby canine kidney cells) (Violini et al. 2002).

NLSs are special category of CPPs: these peptides are able to deliver various cargoes into the cell nucleus via nuclear pores that the peptides recognize using specific nuclear transportation processes (Lange et al. 2007). These lysine- or arginine-rich peptides usually originate from DNA and RNA polymerases. A typical example of an NLS is PKKKRKV, derived from SV-40 antigen (Kalderon et al. 1984).

Other examples of positively charged CPPs are summarized in Table 1.

Table 1. Positively charged CPPs.

\begin{tabular}{lcc}
\hline Name of CPP & AA Structure & Reference \\
\hline AIP6 & RLRWR & Wang et al. (2011) \\
DPV6 & GRPRESGKKRKRKRLKP & de Coupade et al. $(2005)$ \\
HIV-1 TAT (48-60) & GRKKRRQRRRPPQ & Green et al. (1988), Viscidi et al. (1989) \\
IRS-tag & RYIRS & Dong et al. $(2003)$ \\
Mini-penetratin & RRMKWKK & (Moede et al. $(1999)$ \\
Penetratin & RQIKIWFQNRRMKWKK & Derossi et al. $(1994)$ \\
Polyarginines & R8, R9, R10, R12 & Tünnemann et al. $(2007)$ \\
RFF2C & RRRRRRRRFFC & Moulton et al. $(2004)$ \\
\hline
\end{tabular}

\section{Amphipathic CPPS}

Amphipathic (or amphiphilic) CPPs have alternating regions of polar (hydrophilic) amino acids and non-polar (hydrophobic) amino acids in their structure. The resulting charge can be positive, neutral, or negative. Some examples of amphipathic CPPs classified according to their overall charge are shown in Table 2. Among the amphipathic CPPs, proline-rich peptides represent a specific category. A proline residue lacking a hydrogen bond to the nitrogen atom of the pyrrolidine ring contributes to the disruption of the secondary structure of the peptide chain.

\section{Hydrophobic CPPS}

Hydrophobic CPPs have a high content of hydrophobic amino acid residues such as alanine, leucine, isoleucine, phenylalanine, tryptophan, methionine, and tyrosine; these are listed in Table 3.

\section{Other cell-penetrating compounds}

Compounds other than peptides that can also penetrate cell membranes without the need for an energy supply are much less frequently described in the literature. Similarly to peptides, amphiphilic surfactants also contain both hydrophilic and hydrophobic parts. Examples of such compounds are natural saponins, which are used in molecular biology or microbiology as membrane-permeating substances (Wojciechowski et al. 2014).

Another example of cell-penetrating compounds is the group of so-called peptide-like molecules (PLM) with structures resembling a peptide chain. They consist of unnatural $\alpha, \beta$, or $\gamma$-amino acid residues, instead of proteinogenic amino acids or isosteric peptides (Wipf et al. 2009). However, their behavior is similar to that of native peptides. A representative of PLM, the anti-HIV drug ritonavir has also been recently described as an efficient P-glycoprotein inhibitor that significantly enhances cell penetration of polymer conjugates with covalently bound ritonavir, when compared to the polymer alone (Koziolová et al. 2016).

\section{Types of CPP attachment to the cargo}

The attachment of CPP to the cargo that is intended to be delivered into the intracellular compartments can be either covalent (cleavable or non-cleavable) or can be based on non-covalent interactions. Both approaches have their advantages and disadvantages; the choice of the type of bond usually depends on the particular structures of both the CPP and the cargo. The simplest method is based on direct mixing of the two components (the CPP and the cargo) (Kamei et al. 2016). 
Table 2. Amphipathic CPPs.

\begin{tabular}{|c|c|c|}
\hline Name of CPP & AA Structure & Reference \\
\hline \multicolumn{3}{|c|}{ Amphipathic cationic } \\
\hline$C A D Y$ & GLWRALWRLLRSLWRLLWRA & Crombez et al. (2009) \\
\hline$E B-1$ & LIRLWSHLIHIWFQNRRLKWKKK & Lundberg et al. (2007) \\
\hline$h C T(9-32)$ & LGTYTQDFNKFHTFPQTAIGVGAP & Tréhin et al. (2004) \\
\hline PTD4 & YARAAARQARA & Ho et al. (2001) \\
\hline MAP & KLALKALKALKAALKLA & Poon and Gariepy (2007) \\
\hline Pep-1 & KETWWETWWTEWSQPKKRKV & Morris et al. (2001) \\
\hline pVEC & LLIILRRRIRKQAHAHSK & Elmquist et al. (2001) \\
\hline SynB1 & RGGRLSYSRRRFSTSTGR & Rousselle et al. (2000) \\
\hline Transportan & GWTLNSAGYLLGKINLKALAALAKKIL & Pooga et al. (1998) \\
\hline Vpl & APKRKSGVSK & Saphire et al. (2000) \\
\hline \multicolumn{3}{|c|}{ Amphipathic neutral } \\
\hline MAP17 & QLALQLALQALQAALQLA & Scheller et al. (1999) \\
\hline $\operatorname{PreS} 2$ & PLSSIFSRIGDP & Oess and Hildt (2000) \\
\hline \multicolumn{3}{|c|}{ Amphipathic anionic } \\
\hline GALA & WEAALAEALAEALAEHLAEALAEALEALAA & Li et al. (2004) \\
\hline MAP12 & LKTLTETLKELTKTLTEL & Oehlke et al. (1999) \\
\hline \multicolumn{3}{|l|}{ Proline-rich } \\
\hline$(P P R)_{n}$ & (PPR)3, (PPR)4, (PPR)5, (PPR)6 & Daniels and Schepartz (2007) \\
\hline$(P R R)_{n}$ & (PRR)3, (PRR)4, (PRR)5, (PRR)6 & Daniels and Schepartz (2007) \\
\hline$B a c-7$ & RRIRPRPPRLPRPRPRPLPFPRPG & Sadler et al. (2002) \\
\hline SAP & VRLPPPVRLPPPVRLPPP & Martin et al. (2011) \\
\hline
\end{tabular}

Table 3. Hydrophobic CPPs.

\begin{tabular}{lcc}
\hline Name of CPP & AA Structure & Reference \\
\hline$B I P$ & VPMLK(E) & Sawada et al. $(2003)$ \\
$C 105 Y$ & (CSIPPEVKFNK)PFVYLI & Rhee and Davis (2006) \\
$\beta 3$-integrin & VTVLALGALAGVGVG & Liu et al. $(1996)$ \\
$K-F G F$ & AAVLLPVLLAAP & Lin et al. $(1995)$ \\
$N F-\kappa B$ & VQRKRQKLMP & Lin et al. $(1995)$ \\
$P e p-7$ & SDLWEMMMVSLACQY & Gao et al. $(2002)$ \\
$\beta 1-$ tail & YKSAVTTVVNPKYEGK & Liu et al. $(1996)$ \\
\hline
\end{tabular}

\section{Covalent attachment}

A covalent attachment between the CPP and the cargo molecule is the most commonly used bond. There can be either a direct covalent bond between the two components (Goswami et al. 2015), or they can be linked together via transporting systems such as polymer carriers (Golan et al. 2016), metal nanoparticles (de la Fuente and Berry 2005), or liposomes (Ding et al. 2015). The most common types of covalent bond are amide, disulfide (Herce et al. 2013) or triazole-based originating from a "click" reaction (Shabanpoor et al. 2015). Spacers are often used to adjust the optimal distance between the CPP and the cargo. These spacers can be attached to the sidechain functional groups of the CPP, such as the lysine amino group or cysteine thiol group, or even the carboxylic group or amino group at the $\mathrm{C}$ or $\mathrm{N}$-terminus 
of the peptide, respectively. An advanced method of attaching the CPP to another protein (or peptide) molecule is the preparation of a fusion protein using recombinant DNA technology (Mie et al. 2003). However, this method is applicable only when the cargo to be internalized is a protein or another peptide.

\section{Non-covalent approach}

The main advantage of the non-covalent approach is that the complex between the CPP and the cargo is formed upon the mere mixing of the two components. The application of the well-known strong interaction between avidin and biotin (Wierzbicki et al. 2014), or the use of electrostatic interactions between a positively charged CPP and a negatively charged polyanionic transporting system (Xu et al. 2010) or cargo, e.g. siRNA (Peng et al. 2017), are examples of non-covalent methods. The disadvantage of non-covalent attachment is the lower stability of the complex in the body environment.

\section{Cellular uptake mechanisms}

The cellular uptake mechanism of CPPs depends on a variety of factors, such as the type of CPPs, concentration, incubation time, temperature, membrane structure, type of cell, primary and secondary structure of CPP, and cargo type. Direct penetration of CPPs via both energy-independent pathways and energy-dependent pathways (usually related to endocytosis) have been discussed recently (Copolovici et al. 2014, Reissmann 2014). It was found that direct penetration occurs only at high concentration of CPPs, while endocytosis is present in almost all cases (Guidotti et al. 2017).

\section{Direct penetration}

Direct penetration occurs even at a low temperature $\left(4^{\circ} \mathrm{C}\right)$ or in the presence of inhibitors of endocytosis. It is an energy-independent process based on the interaction of positively charged CPPs with negatively charged components of the cell membrane, such as heparan sulfate and a phospholipid barrier. Direct penetration into the cytosol (Murray et al. 2016) involves various mechanisms of CPP entrance, such as pore formation and destabilization of the cell membrane. Pore formation includes the barrel stave model and the toroidal pore model (Madani et al. 2011), while the carpet-like model and inverted micelle formation induce membrane destabilization and direct internalization of CPPs.

The barrel stave model (Fig. 1) involves the helix conformation of the CPP. The hydrophobic residues of the helix structure face toward the hydrophobic tails of the lipid bilayer, and the hydrophilic residues of the CPP form the internal environment of the pore. This model is unique for alamethicin, which induces the formation of transmembrane pores containing a 3-11 parallel helical structure (Brogden 2005).

In addition to the barrel stave model, the toroidal pore model (Fig. 1) is an approach that depends on the helix conformation of the CPP with differences in the mechanism of pore formation. The pores are formed by peptides that are associated with the polar head groups of lipids inside the cell membrane. The hydrophilic core of the toroidal pore is lined with both the inserted peptides and hydrophilic head groups of the phospholipid cell membrane (Matsuzaki et al. 1996, Yang et al. 2001). Magainins, melittin, and protegrins are alpha-helix peptides that induce toroidal pore formation; these toroidal pores are larger and more variable than the barrel stave type (Brogden 2005).

The carpet-like model (Fig. 1) describes the destabilization of the cell membrane (Madani et al. 2011). In this model, peptides are in parallel orientation to the membrane surface. Essential interactions in this model are electrostatic interactions between anionic phospholipid head groups and positively charged peptides. The CPP concentration must be above a threshold concentration and high enough to form the carpet-like membrane coating; consequently, membrane permeation occurs after a sufficient amount of the membrane is covered with CPPs. In the carpet-like model, in contrast with the barrel stave model, the peptides are not internalized into the hydrophobic core. After the hydrophilic groups of the peptides bind to the phospholipid head groups, rotation of the peptide leads to destabilization and reorganization of the cell membrane (Shai 1999). The lipid bilayer transforms into a micelle, forming a transient hole (Khandia et al. 2017).

An inverted micelle (Fig. 1) is formed between two cell membrane bilayers, as a hexagonal structure in which the CPP is surrounded by the hydrophobic part of the membrane (Khandia et al. 2017). In addition to the interaction between the hydrophobic residues of CPPs and the hydrophobic part of the membrane, the interaction between positively charged CPPs and the negatively charged part of the cell membrane has also been shown to be involved (Guo et al. 2016, Islam et al. 2018). The HIV-1 TAT peptide and octaarginine are effectively internalized through inverted micelle formation (Khandia et al. 2017). 


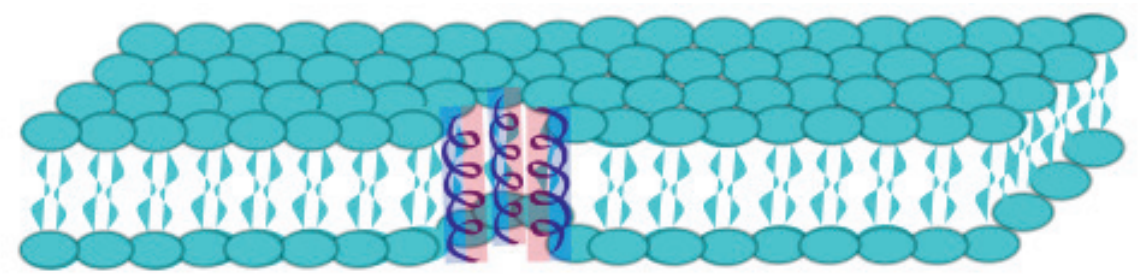

Barrel stave model

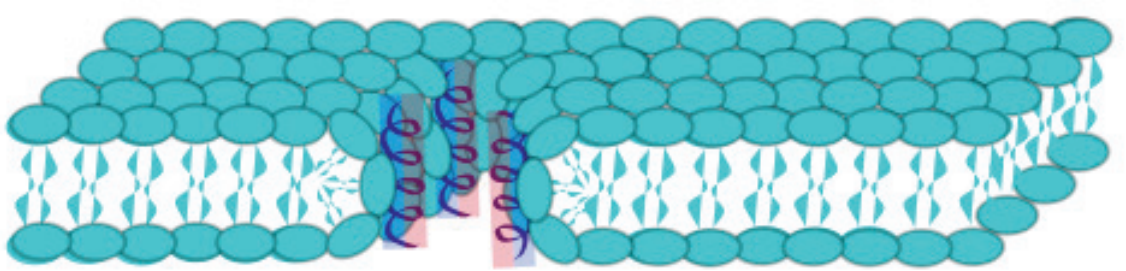

\section{Toroidal pore formation}

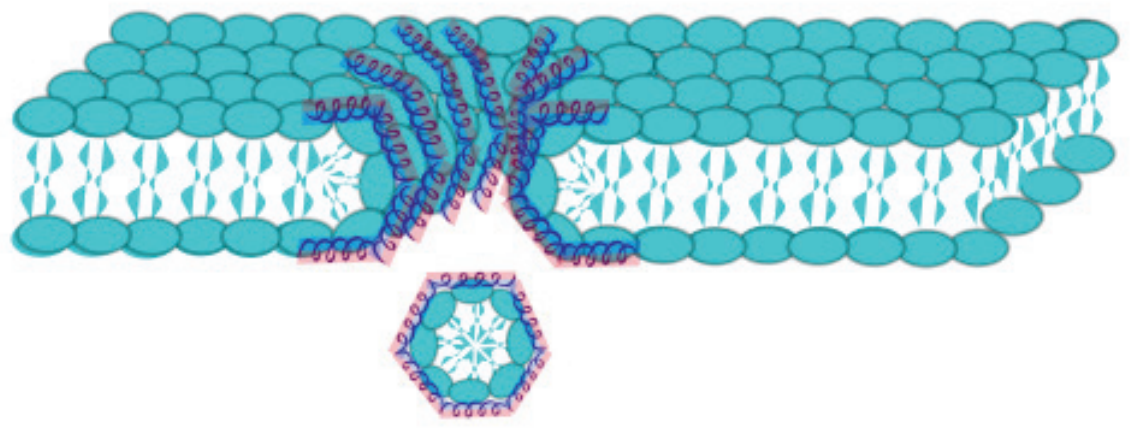

\section{Carpet-like model}

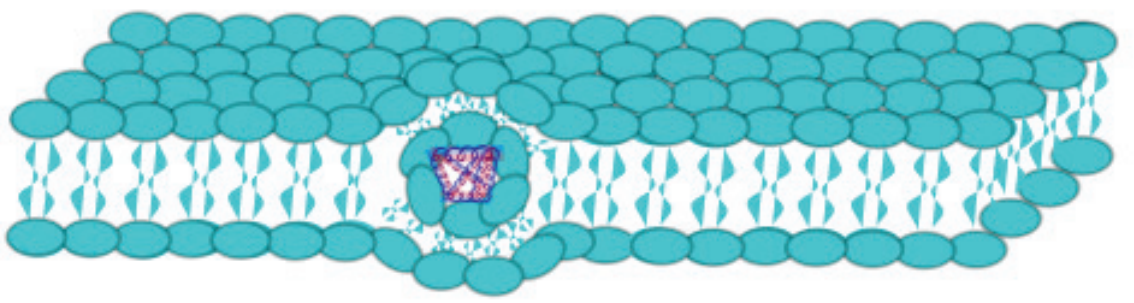

\section{Inverted micelle} formation

Fig. 1. Schematically depicted models of direct penetration of CPPs via cell membrane. The hydrophilic parts of the peptides are colored red and the hydrophobic parts of the peptides are colored blue.

\section{Endocytosis}

The entrance mechanism of CPPs was first described as a receptor-independent and non-endocytic uptake. This presumption was based on observations of fluorescently labeled CPPs in fixed cells: it was found that the fixation of cells could lead to the artificial redistribution of CPPs inside cells. Later, a number of studies showed the contribution of endocytosis to the different CPP internalization mechanisms and their cargo molecules (Richard et al. 2003). Endocytosis is an energy-dependent mechanism and consists of several pathways, including phagocytosis for the uptake of large particles, and pinocytosis for the internalization of the fluid surrounding the cell. Pinocytosis includes 
micropinocytosis, clathrin- and/or caveolin-dependent endocytosis, clathrin- and/or caveolin-independent endocytosis, and dynamin-dependent and/or dynaminindependent endocytosis. CPPs can utilize more endocytic pathways during internalization, and thus increase their uptake into the cells (Heitz et al. 2009). Macropinocytosis results in the formation of vesicles called macropinosomes, which are formed during inward folding of the plasma membrane. Clathrin and caveolin are proteins that are present in the intracellular part of the cell membrane during endocytosis; they are required for the invagination of the membrane and formation of vesicles that are coated with these proteins. The clathrincoated vesicles are a few hundred nanometers in diameter, while the caveolin-coated vesicles have a diameter below one hundred nanometers. Dynamin is a protein involved in the invagination of the cell membrane and is necessary for the formation of these vesicles (Jones 2007).

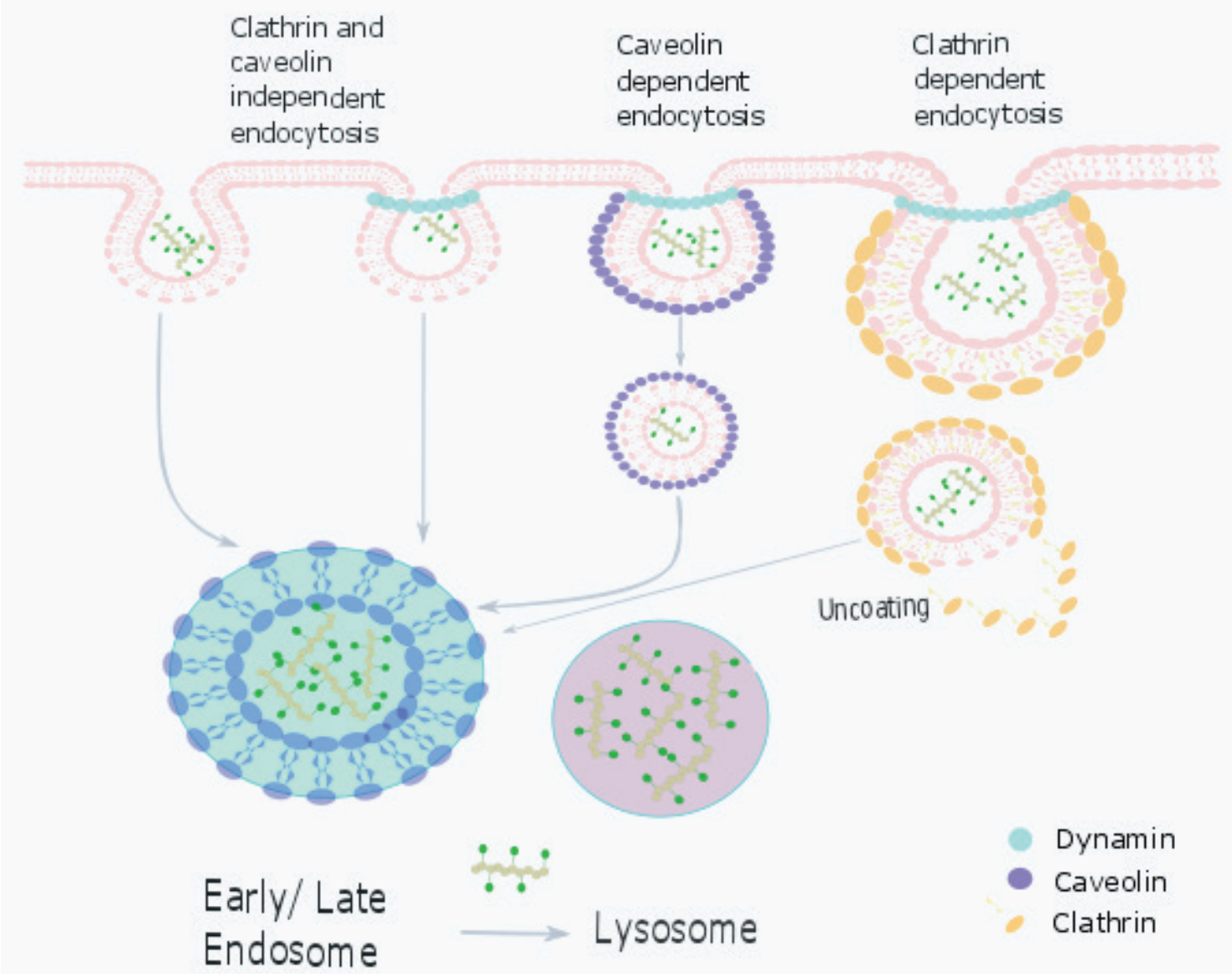

Fig. 2. Cellular uptake of CPPs by endocytic pathways.

\section{Endosomal escape of CPPs}

The route of cellular uptake of the CPP-cargo complex has been discussed in detail above. The limitations of delivery via endocytosis include cargo entrapment inside the endosome and subsequent possible destruction in the acidic lyso-endosome, whereas direct penetration transports the cargo directly to the cell cytoplasm. There is contradictory evidence regarding endosomal accumulation, endosomal escape, and lysosomal degradation. The CPP-cargo complex interacts with phospholipid bis(monoacylglycero)phosphate
(BMP), which is a part of the endosomal membrane. The fusion of membranes of the lysosome and the CPP-cargocontaining endosome is crucial for cargo escape to the cytosol. For example, the TAT peptide induces lipid mixing and subsequent leaky fusion of membranes. Similarly, polyarginines are also able to escape from the late endosome (Appelbaum et al. 2012, Yang et al. 2010).

The changes in $\mathrm{pH}$ values during transitions from early to late endosomes are essential for transition from an inactive to an active membrane-disruptive form of $\mathrm{pH}$-dependent membrane-active peptides (PMAPs), 
e.g. the HA2 peptide (which corresponds to the $23 \mathrm{~N}$-terminal residues of the hemagglutinin HA2 subunit of the influenza virus X31 strain) (Wharton et al. 1988). When inserted into the membrane, PMAPs induce membrane fusion, leakage and lysis (Esbjörner et al. 2007, Turk et al. 2002).

Multivalent CPPs increase endosomolytic activity through stronger interaction with BMPs in membranes, and they escape from endosomes more efficiently than monomeric CPPs. Multivalency can be achieved by attaching a protein oligomerization domain to the CPP, chemical conjugation of CPPs to dendrimers, or by attaching CPPs to branched oligopeptides, such as the fork-like structure of lysine or glutamic acid. However, this approach also presents the following limitations: chemical synthesis of multivalent CPPs is more difficult; there is a higher risk of immunogenic properties; and it is necessary to balance the number of branches of CPP, to elicit a strong enough but not too extensive reaction.

Folded proteins containing a pentaarginine motif were able to escape from endosomes to the cytoplasm (Appelbaum et al. 2012). Indeed, cyclization of argininerich CPPs led to a more efficient cellular uptake and delivery to the cytoplasm and nucleus. For release from endosomes and effective cytosolic delivery, the presence of D- and L-arginine residues is probably necessary, as it was reported that peptides containing only L-arginine (polypeptide R8) were eventually incorporated within endosomes (Ma et al. 2012). Thus, an endosomolytic agent called dfTAT (disulfide-linked TAT) was developed to destabilize endosomes (Najjar et al. 2015) and to enable cargo escape to the cytoplasm.

Another strategy uses CPP-bound calmodulin and a cargo with a calmodulin binding site. After cellular uptake, the level of calcium (which is needed for stable CPP-cargo bonds) decreases, and the cargo leaves the endosome before its transformation to the acidic late endosome (Salerno et al. 2016).

\section{Targeted subcellular localization}

An important advantage of some CPPs is direct transport to the cell organelles through the recognition of specific localization sequences inside the cells.

In cancer treatment, the most promising approach is targeting the nucleus with DNA-damaging agents or nucleic acids for gene therapy, as mentioned above (Cartier and Reszka 2002). Another important target is mitochondria, which are targeted by short artificially designed peptides such as Szeto-Schiller (SS) peptides, rather than by natural sequences (Mahon et al. 2007, Szeto 2006). Moreover, Cerrato et al. developed several CPPs designed especially for mitochondria targeting (Cerrato et al. 2015).

Lysosomes are organelles that are involved in macromolecular turnover, and they provide nutrition by autolyzing dysfunctional organelles during starvation periods. The dysfunction of lysosomal enzymes can lead to the accumulation of substrates that compromise cellular function; this condition is referred to as the lysosomal storage condition (Lübke et al. 2009). Receptors on the cell surface (folate, transferrin, vascular endothelial growth factor) are used for the endosome/lysosome targeting of degradative enzymes (Ni et al. 2006).

Due to the addition of a targeting sequence to the CPP-cargo complex, the cargo was successfully delivered to the nucleus, nucleolus, lysosome, peroxisome, mitochondria, and endoplasmatic reticulum.

\section{Preclinical and clinical use of CPPs}

Several preclinical studies have been performed on experimental animals in the search for an effective model for various therapeutic uses: these include cerebral ischemia, ALS, myocardial injury, cancer, muscular dystrophy, cardiology, anti-prion treatment, and both viral and bacterial infections (Copolovici et al. 2014). Some of these studies reported promising results.

For example, the RI-TAT-p53C' protein was developed to restore the pro-apoptic activity of the p53 protein that is responsible for cell cycle arrest and apoptosis following oncogenic stress (Vousden and $\mathrm{Lu}$ 2002, Snyder et al. 2004). Some of the chemotherapeutics are delivered as prodrugs and metabolized into effective forms that are often insoluble (Meyer-Losic et al. 2008).

CPPs can be used for targeted gene delivery in gene therapy: compared to other procedures, they provide less toxic and significantly more efficient transfection methods. For instance, CPP-DNA complexes are better protected in an extracellular space than naked DNA. In pulmonary treatment, TAT-PEG-poly(ethylene imine) polymers carrying plasmid DNA demonstrated approximately $600 \%$ higher transfection efficiency in vivo than plasmid DNA alone.

Furthermore, CPP-bound siRNAs show higher stability and delivery efficiency in vivo. For instance, 
MPG-8 targets cyclin B1, thus preventing tumor growth in animal models. In the mouse model, the TAT-conjugated system can deliver siRNA of epidermal growth factor receptor (EGFR) and AKT serine/threonine kinase 2 (Akt2) in glioblastoma (Crombez et al. 2009, Michiue et al. 2009).

Currently, over 25 clinical trials involving CPPs are in progress, including some in phase III (LeCher et al. 2017). No immunogenicity and good toleration by patients was shown using the p28 peptide derived from bacterial azurin: this is because p 28 enters the nucleus, then binds to p53 and prevents its degradation, which leads to cancer cell apoptosis (Warso et al. 2013). Moreover, the same protein has been tested in progressive tumors of the central nervous system.

\section{Conclusions}

In this review, we have attempted to summarize the most important cell-penetrating peptides, although there has been insufficient scope to cover all the systems described to date.

Since their discovery, for the last three decades cell-penetrating compounds have been attracting the attention of researchers in various fields. The ability of CPPs to penetrate cell membranes and to deliver various biologically active cargoes into cells is especially relevant to biomedical applications such as drug delivery and diagnostics. With respect to the tremendous progress in solid-phase peptide synthesis, and consequently, also the improved affordability and availability of practically any synthetic peptide, the scientific attractiveness of CPPs is still growing.

\section{Conflict of Interest}

There is no conflict of interest.

\section{Acknowledgements}

The work was supported by the Ministry of Education, Youth and Sports of CR within the National Sustainability Program I (NPU I), Project POLYMAT LO1507.

\section{References}

APPELBAUM JS, LAROCHELLE JR, SMITH BA, BALKIN DM, HOLUB JM, SCHEPARTZ A: Arginine topology controls escape of minimally cationic proteins from early endosomes to the cytoplasm. Chem Biol 19: 819-830, 2013.

BÖHMOVA E, POLA R: Peptide-targeted polymer cancerostatics. Physiol Res 65 (Suppl 2): S153-S164, 2016.

BROGDEN KA: Antimicrobial peptides: Pore formers or metabolic inhibitors in bacteria? Nat Rev Microbiol 3: 238-250, 2005.

CARTIER R, RESZKA R: Utilization of synthetic peptides containing nuclear localization signals for nonviral gene transfer systems. Gene Ther 9: 157-167, 2002.

CERRATO CP, PIRISINU M, VLACHOS EN, LANGEL Ü: Novel cell-penetrating peptide targeting mitochondria. FASEB J 29: 4589-4599, 2015.

COPOLOVICI DM, LANGEL K, ERISTE E, LANGEL Ü: Cell-penetrating peptides: design, synthesis, and applications. ACS Nano 8: 1972-1994, 2014.

CROMBEZ L, ALDRIAN-HERRADA G, KONATE K, NGUYEN QN, MCMASTER GK, BRASSEUR R, HEITZ F, DIVITA G: A new potent secondary amphipathic cell-penetrating peptide for siRNA delivery into mammalian cells. Mol Ther 17: 95-103, 2009.

CROMBEZ L, MORRIS MC, DUFORT S, ALDRIAN-HERRADA G, NGUYEN Q, MC MASTER G, COLL JL, HEITZ F, DIVITA G: Targeting cyclin B1 through peptide-based delivery of siRNA prevents tumour growth. Nucleic Acids Res 37: 4559-4569, 2009.

DANIELS DS, SCHEPARTZ A: Intrinsically cell-permeable miniature proteins based on a minimal cationic PPII motif. J Am Chem Soc 129: 14578-14579, 2007.

DE COUPADE C, FITTIPALDI A, CHAGNAS V, MICHEL M, CARLIER S, TASCIOTT E, DARMON A, RAVEL D, KEARSEY J, GIACCA M, CAILLER F: Novel human-derived cell-penetrating peptides for specific subcellular delivery of therapeutic biomolecules. Biochem J 390: 407-418, 2005.

DE LA FUENTE JM, BERRY CC: Tat peptide as an efficient molecule to translocate gold nanoparticles into the cell nucleus. Bioconjug Chem 16: 1176-1180, 2005. 
DEROSSI D, JOLIOT AH, CHASSAING G, PROCHIANTZ A: The third helix of the Antennapedia homeodomain translocates through biological membranes. J Biol Chem 269: 10444-10450, 1994.

DING Y, SUN D, WANG GL, YANG HG, XU HF, CHEN JH, XIE Y, WANG ZQ: An efficient PEGylated liposomal nanocarrier containing cell-penetrating peptide and $\mathrm{pH}$-sensitive hydrazone bond for enhancing tumor-targeted drug delivery. Int J Nanomedicine 10: 6199-6214, 2015.

DONG C, LYU SC, KRENSKY AM, CLAYBERGER C: DQ 65-79, a peptide derived from HLA class II, mimics p21 to block T cell proliferation. J Immunol 171: 5064-5070, 2003.

ELMQUIST A, LINDGREN M, BARTFAI T, LANGEL U: VE-cadherin-derived cell-penetrating peptide, pVEC, with carrier functions. Exp Cell Res 269: 237-244, 2001.

ESBJÖRNER EK, OGLECKA K, LINCOLN P, GRÄSLUND A, NORDÉN B: Membrane binding of pH-sensitive influenza fusion peptides. Positioning, configuration, and induced leakage in a lipid vesicle model. Biochemistry 46: 13490-13504, 2007.

FUTAKI S, SUZUKI T, OHASHI W, YAGAMI T, TANAKA S, UEDA K, SUGIURA Y: Arginine-rich peptides. An abundant source of membrane-permeable peptides having potential as carriers for intracellular protein delivery. J Biol Chem 276: 5836-5840, 2001.

GAO C, MAO S, DITZEL HJ, FARNAES L, WIRSCHING P, LERNER RA, JANDA KD: A cell-penetrating peptide from a novel pVII-pIX phage-displayed random peptide library. Bioorg Med Chem 10: 4057-4065, 2002.

GOLAN M, FEINSHTEIN V, DAVID A: Conjugates of HA2 with octaarginine-grafted HPMA copolymer offer effective siRNA delivery and gene silencing in cancer cells. Eur J Pharm Biopharm 109: 103-112, 2016.

GOSWAMI D, VITORINO HA, TERESA MACHINI M, ESPOSITO BP: Self-assembled penetratin-deferasirox micelles as potential carriers for hydrophobic drug delivery. Biopolymers 104: 712-719, 2015.

GREEN M, LOEWENSTEIN PM: Autonomous functional domains of chemically synthesized human immunodeficiency virus tat trans-activator protein. Cell 55: 1179-1188, 1988.

GUIDOTTI G, BRAMBILLA L, ROSSI D: Cell-penetrating peptides: from basic research to clinics. Trends Pharmacol Sci 38: 406-424, 2017.

GUO Z, PENG H, KANG J, SUN D: Cell-penetrating peptides: possible transduction mechanisms and therapeutic applications. Biomed Rep 4: 528-534, 2016.

HAMPL F, RÁDL S, PALEČEK J: Farmakochemie. Third Edition, University of Chemistry and Technology in Prague, $2015,640 \mathrm{p}$.

HEITZ F, MORRIS MC, DIVITA G: Twenty years of cell-penetrating peptides: from molecular mechanisms to therapeutics. Br J Pharmacol 157: 195-206, 2009.

HERCE HD, DENG W, HELMA J, LEONHARDT H, CARDOSO MC: Visualization and targeted disruption of protein interactions in living cells. Nat Commun 4: 1-8, 2013.

HO A, SCHWARZE SR, MERMELSTEIN SJ, WAKSMAN G, DOWDY SF: Synthetic protein transduction domains: Enhanced transduction potential in vitro and in vivo. Cancer Res 61: 474-477, 2001.

ISLAM MZ, SHARMIN S, MONIRUZZAMAN M, YAMAZAKI M: Elementary processes for the entry of cellpenetrating peptides into lipid bilayer vesicles and bacterial cells. Appl Microbiol Biotechnol 102: 3879-3892, 2018.

JONES AT: Macropinocytosis: Searching for an endocytic identity and role in the uptake of cell penetrating peptides. J Cell Mol Med 11: 670-684, 2007.

KALDERON D, ROBERTS BL, RICHARDSON WD, SMITH AE: A short amino-acid sequence able to specify nuclear localization. Cell 39: 499-509, 1984.

KAMEI N, SHINGAKI T, KANAYAMA Y, TANAKA M, ZOCHI R, HASEGAWA K, WATANABE Y, TAKEDAMORISHITA M: Visualization and quantitative assessment of the brain distribution of insulin through nose-tobrain delivery based on the cell-penetrating peptide noncovalent strategy. Mol Pharm 13: 1004-1011, 2016.

KHANDIA R, MUNJAL A, KUMAR A, SINGH G, KARTHIK K, DHAMA K: Cell penetrating peptides: Biomedical/therapeutic applications with emphasis as promising futuristic hope for treating cancer. Int J Pharmacol 13: 677-689, 2017. 
KOZIOLOVÁ E, MACHOVÁ D, POLA R, JANOUŠKOVÁ O, CHYTIL P, LAGA R, FILIPPOV SK, ŠUBR V, ETRYCH T, PECHAR M: Micelle-forming HPMA copolymer conjugates of ritonavir bound via a pH-sensitive spacer with improved cellular uptake designed for enhanced tumor accumulation. J Mater Chem B 4: 7620-7629, 2016.

LANGE A, MILLS RE, LANGE CJ, STEWART M, DEVINE SE, CORBETT AH: Classical nuclear localization signals: definition, function, and interaction with importin alpha. J Biol Chem 282: 5101-5105, 2007.

LECHER JC, NOWAK SJ, MCMURRY JL: Breaking in and busting out: cell-penetrating peptides and the endosomal escape problem. Biomol Concepts 8: 131-141, 2017.

LI WJ, NICOL F, SZOKA FC: GALA: a designed synthetic pH-responsive amphipathic peptide with applications in drug and gene delivery. Adv Drug Deliv Rev 56: 967-985, 2004.

LIN YZ, YAO SY, VEACH RA, TORGENSON TR, HAWIGER J: Inhibition of nuclear translocation of transcription factor NF-KAPPA-B by a synthetic peptide containing a cell membrane-permeable motif and nuclear localization sequence. $J$ Biol Chem 270: 14255-14258, 1995.

LIU XY, TIMMONS S, LIN YZ, HAWIGER J: Identification of a functionally important sequence in the cytoplasmic tail of integrin beta(3) by using cell-permeable peptide analogs. Proc Natl Acad Sci U S A 93: 11819-11824, 1996.

LÜBKE T, LOBEL P, SLEAT DE: Proteomics of the lysosome. Biochim Biophys Acta 1793: 625-635, 2009.

LUNDBERG P, EL-ANDALOUSSI S, SUTLU T, JOHANSSON H, LANGEL U: Delivery of short interfering RNA using endosomolytic cell-penetrating peptides. J Pept Sci 21: 2664-2671, 2007.

MA Y, GONG C, MA Y, FAN F, LUO M, YANG F, ZHANG YH: Direct cytosolic delivery of cargoes in vivo by a chimera consisting of D- and L-arginine residues. J Control Release 162: 286-294, 2012.

MADANI F, LINDBERG S, LANGEL Ü, FUTAKI S, GRÄSLUND A: Mechanisms of cellular uptake of cell-penetrating peptides. J Biophys 2011: 414729, 2011.

MAHON KP, POTOCKY TB, BLAIR D, ROY MD, STEWART KM, CHILES TC, KELLEY SO: Deconvolution of the cellular oxidative stress response with organelle-specific peptide conjugates. Chem Biol 14: 923-930, 2007.

MARTÍN I, TEIXIDÓ M, GIRALT E: Design, synthesis and characterization of a new anionic cell-penetrating peptide: SAP(E). Chembiochem 12: 896-903, 2011.

MATSUZAKI K, MURASE O, FUJII N, MIYAJIMA K: An antimicrobial peptide, magainin 2, induced rapid flip-flop of phospholipids coupled with pore formation and peptide translocation. Biochemistry 35: 11361-11368, 1996.

MEYER-LOSIC F, NICOLAZZI C, QUINONERO J, RIBES F, MICHEL M, DUBOIS V, DE COUPADE C, BOUKAISSI M, CHÉNÉ AS, TRANCHANT I, ARRANZ V, ZOUBAA I, FRUCHART JS, RAVEL D, KEARSEY J: DTS-108, a novel peptidic prodrug of SN38: in vivo efficacy and toxicokinetic studies. Clin Cancer Res 14: 2145-2153, 2008.

MICHIUE H, EGUCHI A, SCADENG M, DOWDY SF: Induction of in vivo synthetic lethal RNAi responses to treat glioblastoma. Cancer Biol Ther 8: 2306-2313, 2009.

MIE K, MØRCK NH: Cell-penetrating peptides as carriers for oral delivery of biopharmaceuticals. Basic Clin Pharmacol Toxicol 118: 99-106, 2015.

MIE M, TAKAHASHI F, FUNABASHI H, YANAGIDA Y, AIZAWA M, KOBATAKE E: Intracellular delivery of antibodies using TAT fusion protein A. Biochem Biophys Res Commun 310: 730-734, 2003.

MOEDE T, LEIBIGER B, POUR HG, BERGGREN PO, LEIBIGER IB: Identification of a nuclear localization signal, RRMKWKK, in the homeodomain transcription factor PDX-1. FEBS Lett 461: 229-234, 1999.

MORRIS MC, DEPOLLIER J, MERY J, HEITZ F, DIVITA G: A peptide carrier for the delivery of biologically active proteins into mammalian cells. Nat Biotechnol 19: 1173-1176, 2001.

MOULTON HM, NELSON MH, HATLEVIG SA, REDDY MT, IVERSEN PL: Cellular uptake of antisense morpholino oligomers conjugated to arginine-rich peptides. Bioconjug Chem 15: 290-299, 2004.

MURRAY B, PEARSON CS, ARANJO A, CHERUPALLA D, BELFORT G: Mechanism of four de novo designed antimicrobial peptides. J Biol Chem 291: 25706-25715, 2016.

NAJJAR K, ERAZO-OLIVERAS A, PELLOIS JP: Delivery of proteins, peptides or cell-impermeable small molecules into live cells by incubation with the endosomolytic reagent dfTAT. J Vis Exp 103: 1-9, 2015. 
NI X, CANUEL M, MORALES CR: The sorting and trafficking of lysosomal proteins. Histol Histopathol 21: 899-913, 2006.

OEHLKE J, SCHELLER A, JANEK K, WIESNER B, KRAUSE E, BEYERMANN M, BIENERT M: Rapid translocation of amphipathic alpha-helical and beta-sheet-forming peptides through plasma membranes of endothelial cells. In: Peptide Science - Present and Future. SHIMONISHI Y. (ed.), Springer Dordrecht, 1999, pp 782-783.

OESS S, HILDT E: Novel cell permeable motif derived from the PreS2-domain of hepatitis-B virus surface antigens. Gene Ther 7: 750-758, 2000.

PENG J, RAO Y, YANG X, JIA J, WU Y, LU J, TAO Y, TU W: Targeting neuronal nitric oxide synthase by a cell penetrating peptide Tat-LK15/siRNA bioconjugate. Neurosci Lett 650: 153-160, 2017.

POOGA M, HÄLLBRINK M, ZORKO M, LANGEL U: Cell penetration by transportan. FASEB J 12: 67-77, 1998.

POON GMK, GARIEPY J: Cell-surface proteoglycans as molecular portals for cationic peptide and polymer entry into cells. Biochem Soc Trans 35: 788-793, 2007.

REISSMANN S: Cell penetration: Scope and limitations by the application of cell-penetrating peptides. $J$ Pept Sci 20: 760-784, 2014.

RESHETNYAK YK, ANDREEV OA, LEHNERT U, ENGELMAN DM: Translocation of molecules into cells by pH-dependent insertion of a transmembrane helix. Proc Natl Acad Sci U S A 103: 6460-6465, 2006.

RHEE M, DAVIS P: Mechanism of uptake of C105Y, a novel cell-penetrating peptide. J Biol Chem 281: 1233-1240, 2006.

RICHARD JP, MELIKOV K, VIVES E, RAMOS C, VERBEURE B, GAIT MJ, CHERNOMORDIK LV, LEBLEU B: Cell-penetrating peptides: A reevaluation of the mechanism of cellular uptake. $J$ Biol Chem 278: 585-590, 2003.

ROUSSELLE C, CLAIR P, LEFAUCONNIER JM, KACZOREK M, SCHERRMANN JM, TEMSAMANI J: New advances in the transport of doxorubicin through the blood-brain barrier by a peptide vector-mediated strategy. Mol Pharmacol 57: 679-686, 2000.

SADLER K, EOM KD, YANG JL, DIMITROVA Y, TAM JP: Translocating proline-rich peptides from the antimicrobial peptide bactenecin 7. Biochemistry 41: 14150-14157, 2002.

SALERNO JC, NGWA VM, NOWAK SJ, CHRESTENSEN CA, HEALEY AN, MCMURRY JL: Novel cell-penetrating peptide-adaptors effect intracellular delivery and endosomal escape of protein cargos. $J$ Cell Sci 129: 2473-2474, 2016.

SAPHIRE ACS, GUAN TL, SCHIRMER EC, NEMEROW GR, GERACE L: Nuclear import adenovirus DNA in vitro involves the nuclear protein import pathway and hsc70. J Biol Chem 275: 4298-4304, 2000.

SAWADA M, HAYES P, MATSUYAMA S: Cytoprotective membrane-permeable peptides designed from the Bax-binding domain of Ku70. Nat Cell Biol 5: 352-357, 2003.

SCHELLER A, OEHLKE J, WIESNER B, DATHE M, KRAUSE E, BEYERMANN M, MELZIG M, BIENERT M: Structural requirements for cellular uptake of alpha-helical amphipathic peptides. J Pept Sci 5: 185-194, 1999.

SHABANPOOR F, MCCLOREY G, SALEH AF, JAERVER P, WOOD MJA, GAIT MJ: Bi-specific splice-switching PMO oligonucleotides conjugated via a single peptide active in a mouse model of Duchenne muscular dystrophy. Nucleic Acids Res 43: 29-39, 2015.

SHAI Y: Mechanism of the binding, insertion and destabilisation of phospholipid bilayer membranes by alpha-helical antimicrobial and cell non-selective membrane-lytic peptides. Biochim Biophys Acta 1462: 55-70, 1999.

SNYDER EL, MEADE BR, SAENZ CC, DOWDY SF: Treatment of terminal peritoneal carcinomatosis by a transducible p53-activating peptide. PLoS Biol 2: 186-193, 2004.

SZETO HH: Mitochondria-targeted peptide antioxidants: Novel neuroprotective agents. AAPS J 8: E521-E531, 2006.

TRÉHIN R, KRAUSS U, MUFF R, MEINECKE M, BECK-SICKINGER AG, MERKLE HP: Cellular internalization of human calcitonin derived peptides in MDCK monolayers: A comparative study with Tat(47-57) and Penetratin(43-58). Pharm Res 21: 33-42, 2004.

TÜNNEMANN G, TER-AVETISYAN G, MARTIN MR, STÖCKL M, HERRMANN A, CARDOSO MC: Live-cell analysis of cell penetration ability and toxicity of oligo-arginines. J Pept Sci 14: 469-476, 2007. 
TURK MJ, REDDY JA, CHMIELEWSKI JA, LOW PS: Characterization of a novel pH-sensitive peptide that enhances drug release from folate-targeted liposomes at endosomal pHs. Biochim Biophys Acta 1559: 56-68, 2002.

VIOLINI S, SHARMA V, PRIOR JL, DYSZLEWSKI M, PIWNICA-WORMS D: Evidence for a plasma membranemediated permeability barrier to tat basic domain in well-differentiated epithelial cells: Lack of correlation with heparan sulfate. Biochemistry 41: 12652-12661, 2002.

VISCIDI RP, MAYUR K, LEDERMAN HM, FRANKEL AD: Inhibition of antigen-induced lymphocyte proliferation by Tat protein from HIV-1. Science 246: 1606-1608, 1989.

VIVÈS E, BRODIN P, LEBLEU B: A truncated HIV-1 Tat protein basic domain rapidly translocates through the plasma membrane and accumulates in the cell nucleus. J Biol Chem 272: 16010-16017, 1997.

VOUSDEN KH, LU X: Live or let die: the cell's response to p53. Nat Rev Cancer 2: 594-604, 2002.

WANG YF, XU X, FAN X, ZHANG C, WEI Q, WANG X, GUO W, XING W, YU J, YAN JL, LIANG HP: A cell-penetrating peptide suppresses inflammation by inhibiting NF-kB signaling. Mol Ther 19: 1849-1857, 2011.

WARSO MA, RICHARDS JM, MEHTA D, CHRISTOV K, SCHAEFFER C, RAE BRESSLER L, YAMADA T, MAJUMDAR D, KENNEDY SA, BEATTIE CW, DAS GUPTA TK: A first-in-class, first-in-human, phase I trial of p28, a non-HDM2-mediated peptide inhibitor of p53 ubiquitination in patients with advanced solid tumours. Br J Cancer 108: 1061-1070, 2013.

WHARTON SA, MARTIN SR, RUIGROK RW, SKEHEL JJ, WILEY DC: Membrane fusion by peptide analogues of influenza virus hemagglutinin. J Gen Virol 69: 1847-1857, 1988.

WIERZBICKI PM, KOGUT-WIERZBICKA M, RUCZYNSKI J, SIEDLECKA-KROPLEWSKA K, KASZUBOWSKA L, RYBARCZYK A, ALENOWICZ M, REKOWSKI P, KMIEC Z: Protein and siRNA delivery by transportan and transportan 10 into colorectal cancer cell lines. Folia Histochem Cytobiol 52: 270-280, 2014.

WIPF P, XIAO J, STEPHENSON CRJ: Peptide-Like Molecules (PLMs): A journey from peptide bond isosteres to gramicidin S mimetics and mitochondrial targeting agents. Chimia (Aarau) 63: 764-775, 2009.

WOJCIECHOWSKI K, ORCZYK M, GUTBERLET T, TRAPP M, MARCINKOWSKI K, KOBIELA T, GEUE T: Unusual penetration of phospholipid mono- and bilayers by Quillaja bark saponin biosurfactant. Biochim Biophys Acta 1838: 1931-1940, 2014.

XU Y, LIU BR, LEE HJ, SHANNON KB, WINIARZ JG, WANG TC, CHIANG HJ, HUANG YW: Nona-arginine facilitates delivery of quantum dots into cells via multiple pathways. J Biomed Biotechnol 2010: 948543, 2010.

YANG L, HARROUN TA, WEISS TM, DING L, HUANG HW: Barrel-stave model or toroidal model? A case study on melittin pores. Biophys $J$ 81: 1475-1485, 2001.

YANG ST, ZAITSEVA E, CHERNOMORDIK LV, MELIKOV K: Cell-penetrating peptide induces leaky fusion of liposomes containing late endosome-specific anionic lipid. Biophys $J$ 99: 2525-2533, 2010. 